\title{
Use of Scanning as a Complementary Method for Forensic Document Expertise
}

\author{
María Cecilia Galíndez ${ }^{*}$; Cristina Reneé Salgado ${ }^{2}$, Gisela Forlín ${ }^{3}$, Sandra Vandecaveye ${ }^{4}$ y Silvia \\ Díaz $^{5}$
}

1-2 Servicio de Microscopia Electrónica de Barrido. Universidad Nacional del Nordeste. Sgto. Cabral 2131. W3400CEI, W3400 CEI, Corrientes. Argentina.

3-4-5 Instituto de Ciencias Criminalísticas y Criminología. Universidad Nacional del Nordeste. Catamarca 375, W3400CEI, W3400 CEI, Corrientes. Argentina.

* Corresponding author: meb.unne@hotmail.com

Scanning has many applications in the study of biological and material samples [1,2,3,4,5]. Public and private documents are liable to be altered by different methods. To detect fraudulent alterations several techniques are used, such as, visual, chemical and comparison techniques, as well as a series of different and complementary methods of expertise. The aim of this work was to determine differences between three types of printing on paper. The evaluated methods were printing with inkjet printer, toner and photocopy using optical and scanning electron microscopy techniques. The samples were observed with Leica DM500 and images were taken with Leica ICC50 W. Samples were mounted on aluminium sheets bonded with two-sided tape and then coated with gold using a sputter coater Denton Vacuum Desk II. Observations were made with a JEOL 5800LV SEM equipment. The following working conditions were employed: - high vacuum, -electrons acceleration voltage $15 \mathrm{KV}$, -working distance $20 \mathrm{~mm}$, - digital images were captured at different magnifications.

The conducted study allows us to arrive to the following preliminary conclusions: prints that involve heat: laser printer (sample 4), toner (sample 6), laser colour photocopy (sample 8) and laser B\&W printer (sample 11), had an effect on the papers' fibres, leaving an impression seen on the SEM. On the other hand, samples printed with the inkjet printer (sample 5,9) had no effect on the fibres, except for sample 7 where a slight impression was seen. A similar result was seen on the offset paper, in which the impression was made by transference.

Significant differences were observed between the three printing types. The application of scanning observation techniques allows determining the type of printing made on paper, which means, this technique can be used in forensic expertise to recognize fraudulent alterations of public documents in the area of Documentology.

More studies are required in order to determine if this complimentary method is reliable and chromatographic analysis can be made to observe ink's components (e.g. establish a comparison between alternative and original ink). Finally, scanning observation techniques are complimentary to optical microscope analysis techniques allowing the expert to complete the analysis of the document under review [8]. 


\section{References}

[1] C.R. Salgado y M.C. Galíndez. Acta Microscópica, Vol. 25 Supp. A., 2016http://samicargentina.org

[2] V. Sorrivas de Lozano y J. Morales. 1986. Introducción a la microscopia electrónica. CRIBABB. Bahía Blanca. Argentina.

[3] V. Sorrivas de Lozano, M.J. Yañez y A. Morales. 2014. Principios y Práctica de la Microscopía Electrónica, UAT - CONICET. Bahía Blanca. Argentina.

[4] J.I. Goldstein, et al. 1992. Scanning Electron Microscopy and X-Ray Microanalysis, Segunda Edición, New York.

[5] S.I. Vandecaveye y F. Galassi. 2003. "Sine Qua Non” Revista Científica de Pericias Caligráficas y Documentoscopía. Revista Semestral N 6. Diciembre de 2003, pág. 39-43.

[6] P.R. Roldan. 2006.Digitalización de Imágenes en la Pericia Caligráfica. Ediciones La Rocca. Buenos Aires.

[7] J.O. Silveyra. 2005. Investigación Científica del Delito. 2. Peritajes Scopométricos. Ediciones La Rocca. Buenos Aires.

[8] The authors acknowledge funding from the Secretaría General de Ciencia y Técnica-Universidad Nacional del Nordeste.
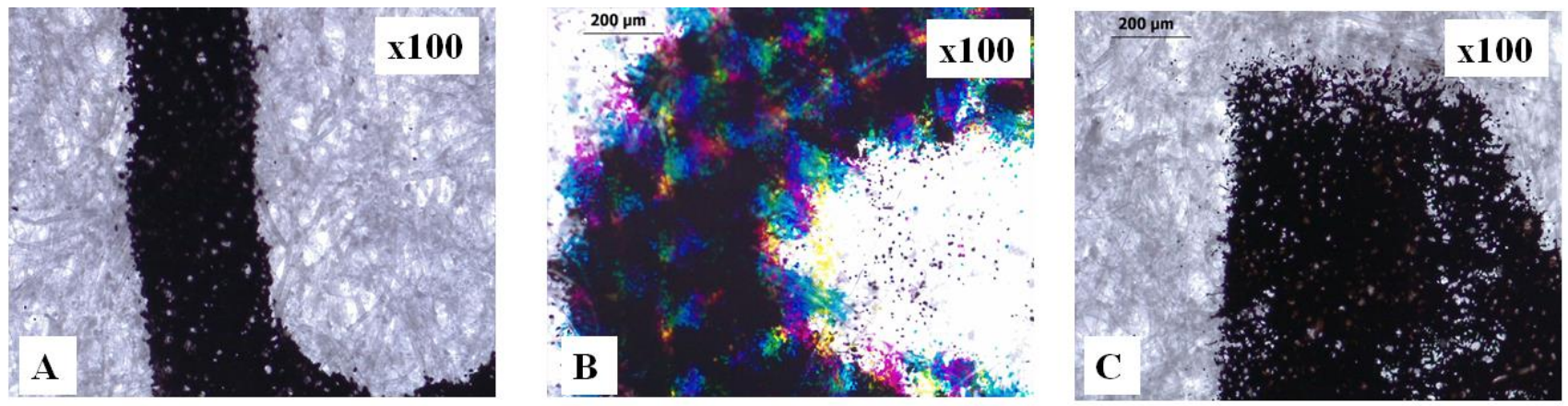

Figure 1. Optical microscope. Images of prints with: A, toner dust laser printer (sample 4). B, laser colour photocopy (sample 8). C, inkjet B\&W printer (sample 11).
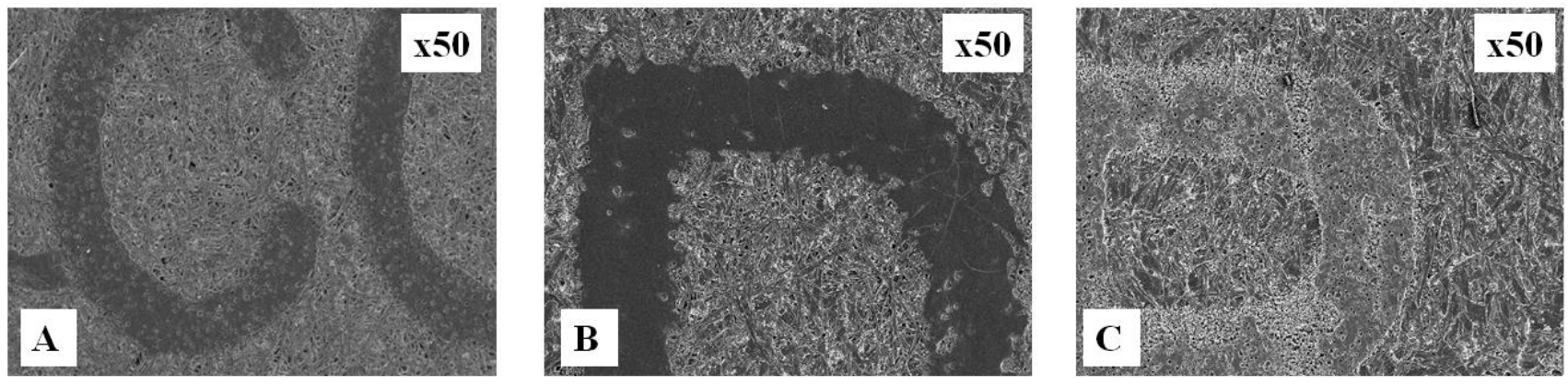

Figure 2. Scanning electron microscope. Images of prints with: A, toner dust laser printer (sample 4). B, laser colour photocopy (sample 8). C, inkjet B\&W printer (sample 11). 